Esta publicación cientifica en formato digital es continuidad de la revista impresa ISSN-Versión Impresa 0798-1406 / ISSN-Versión on line 2542-3185Depósito legal pp
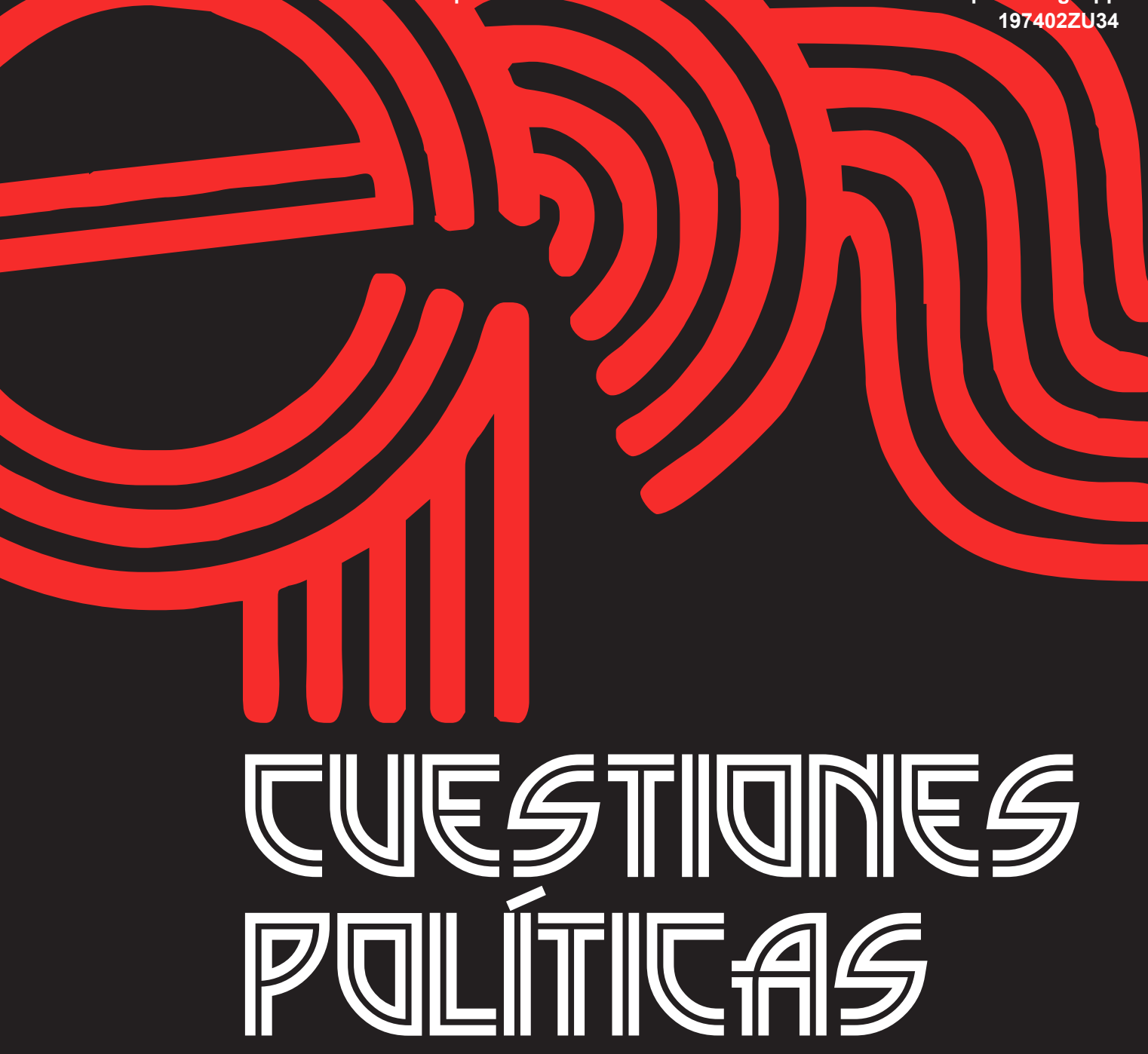

Instituto de Estudios Políticos y Derecho Público "Dr. Humberto J. La Roche" de la Facultad de Ciencias Jurídicas y Políticas de la Universidad del Zulia Maracaibo, Venezuela
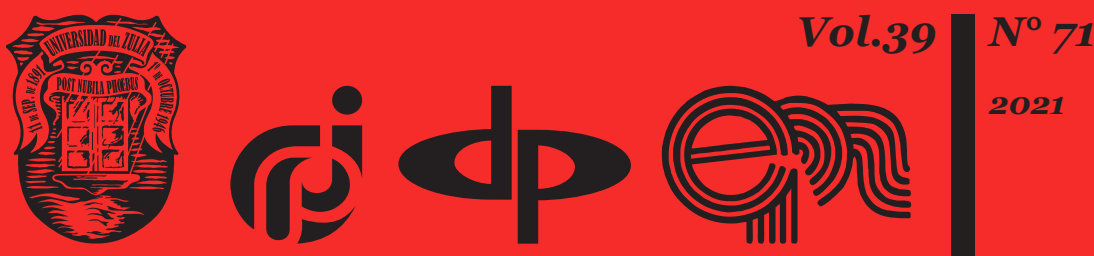


\title{
Legal Mechanisms for Protection of the Rights of Participants in Contractual and Non-Contractual Legal Relations
}

\author{
DOI: https://doi.org/10.46398/cuestpol.3971.07
}

\author{
Serhii S. Sviatoshniuk * \\ Liliia O. Bakalo ** \\ Oleg V. Bilostotskyi *** \\ Serhii F. Gut ${ }^{* * *}$ \\ Oleg I. Chaikovskyi ***** \\ Oleksandr M. Zaiets $* * * * *$
}

\section{Abstract}

The aim of this study is a comprehensive analysis of legal mechanisms to protect the rights of participants in contractual and non-contractual relations based on the experience of foreign countries, namely: Australia, Brazil, Spain, Mexico, Germany, Portugal, Turkey, France, and Switzerland. This research involved the following methods: sociological analysis, system-structural and comparative methods, logical-semantic and formal-logical methods, as well as the dialectical method. Our study resulted in identification of the main characteristics and features of legal mechanisms to protect the rights of participants in contractual and non-contractual relations of each of the studied countries. As a result, we drew conclusions about the need to update the regulatory framework of most of the said countries. The further use of mechanisms for legal protection of the rights of participants

* $\quad$ Postgraduate Student, Department of the Civil Law Disciplines, Faculty of Economics and Law, Odessa I. I. Mechnikov National University, 65082, Odesa, Ukraine. ORCID ID: https://orcid.org/ooooooo1-5371-753X

** Postgraduate Student, Department of Constitutional Law and Justice, Faculty of Economics and Law, Odessa I. I. Mechnikov National University, 65082, Odesa, Ukraine. ORCID ID: https://orcid. org/oooo-0oo2-2948-3945

*** Postgraduate Student, Department of Constitutional Law and Justice, Faculty of Economics and Law, Odessa I. I. Mechnikov National University, 65082, Odesa, Ukraine. ORCID ID: https://orcid. org/oooo-0o03-0692-3247

**** Postgraduate Student, Department of Constitutional Law and Justice, Faculty of Economics and Law, Odessa I. I. Mechnikov National University, 65082, Odesa, Ukraine. ORCID ID: https://orcid. org/oooo-0002-8175-8870

**** Postgraduate Student, Department of Constitutional Law and Justice, Faculty of Economics and Law, Odessa I. I. Mechnikov National University, 65082, Odesa, Ukraine. ORCID ID: https://orcid. org/oooo-0oo1-9694-3406

***** PhD in Law, Professor, Department of Cybersecurity and Information Support, Odessa State University of Internal Affairs, 65014, Odesa, Ukraine. ORCID ID: https://orcid.org/oooo-0002-44265241 
Serhï S. Sviatoshniuk, Liliia O. Bakalo, Oleg V. Bilostotskyi, Serhii F. Gut, Oleg I. Chaikovskyi y Oleksandr M. Zaiets

in contractual and non-contractual relations will help ensure their real and effective protection.

Keywords: protection of rights; legal relations; obligations; legal mechanisms; Contractual and non-Contractual legal relationships.

\section{Mecanismos Legales para la Protección de los Derechos de los Participantes en las Relaciones Legales Contractuales y no Contractuales}

\section{Resumen}

El objetivo de este estudio fue un análisis integral de los mecanismos legales para proteger los derechos de los participantes en las relaciones contractuales y extracontractuales basado en la experiencia de varios países, a saber: Australia, Brasil, España, México, Alemania, Portugal, Turquía, Francia y Suiza. Esta investigación involucró los siguientes métodos: análisis sociológico, métodos sistémicos-estructurales y comparativos, métodos lógico-semánticos y formal-lógicos, así como el método dialéctico. El artículo resultó en la identificación de las principales características y rasgos de los mecanismos legales para proteger los derechos de los participantes en las relaciones contractuales y extracontractuales de cada uno de los países estudiados. Como resultado, sacamos conclusiones sobre la necesidad de actualizar el marco regulatorio de la mayoría de dichos países. El uso adicional de mecanismos para la protección legal de los derechos de los participantes en relaciones contractuales y extracontractuales ayudará a asegurar su protección real y efectiva.

Palabras clave: protección de derechos; relaciones legales; obligaciones; mecanismos legales; relaciones legales Contractuales y no Contractuales.

\section{Introduction}

Research topicality: Legal mechanisms for the protection of the rights of participants in contractual and non-contractual legal relations, first of all, allow preventing, ceasing violations of rights or restoring the violated rights of participants in such legal relations. It should be noted that any person has the right to protection of his/her right and interest, which does not contradict the principles of law, the requirements of fairness, integrity and reasonability. 
Ways and methods of protection of participants in contractual and noncontractual legal relations are directly enshrined in law, which gives certain guarantees to participants in the proceedings to restore (recognize) violated (disputed) rights and to influence such an offender through the state.

Legal protection of contractual and/or non-contractual legal relations is carried out in the manner prescribed by law, that is through the use of appropriate forms, means and methods of protection. It should be noted that the legal protection of participants in legal relations directly depends on the country to which the parties are residents, because the regulations of such a state are applied in the event of a dispute.

Problems of legal mechanisms to protect the rights of participants in contractual and non-contractual relations in the scientific literature are also considered as contractual and non-contractual obligations. A comprehensive analysis of research by European scholars shows that the scope of legal mechanisms for the protection of participants in contractual and non-contractual relations is quite ambiguous.

As of 2021, Ukraine has the provisions on legal protection of both contractual and non-contractual legal relations, but the level of their protection cannot guarantee the protection of the rights and interests of the participants in these legal relations. The same trend is observed in other foreign countries.

The object of the study is the social relations that have developed in the process of legal protection of the rights of participants in contractual and non-contractual relations.

The subject of the study are the conditions of contractual and noncontractual legal relations, the violation of which may evoke a need for a legal mechanism to protect their participants.

The aim of this study is a comprehensive analysis of legal mechanisms to protect the rights of participants in contractual and non-contractual relations on the example of the experience of foreign countries. The identification of the main legal provisions, which are the basis for the regulation of the legal protection for participants in contractual and noncontractual legal relations, allowed determining the effectiveness of the legal protection for participants in such legal relations in these countries. The main objectives include:

- the issue of understanding of contractual and non-contractual legal relations by the participants as a type of legal relations that requires effective legal protection.

- analysis of legal mechanisms for protection of the rights of participants in contractual and non-contractual legal relations and the practice of their application in foreign countries. 
Serhii S. Sviatoshniuk, Liliia O. Bakalo, Oleg V. Bilostotskyi, Serhii F. Gut, Oleg I. Chaikovskyi y Oleksandr M. Zaiets

150

Legal Mechanisms for Protection of the Rights of Participants in Contractual and Non-Contractual Legal Relations

- determining the level of effectiveness of laws and regulations on the legal protection of the rights of participants in contractual and noncontractual relations.

\section{Literature Review}

Complex qualification issues often arise when concluding unnamed contracts in the regulation of contractual and non-contractual relations. Kanashevskii (2019) notes that due to differences in national legal norms, certain types of legal relations can be included only in the legislation of one country (so-called contracts) and can be considered as mixed contracts (a special type of agreements).

The Brazilian Civil Code describes the civil law system with strong legislation and relatively predictable case law on complex legal relations, remedies, and rights against breach of obligations. In regulating the legal protection of contractual and non-contractual legal relations in the next few years, the market expects the development of legislation to introduce new rules with appropriate changes in the legal protection of contractual and non-contractual legal relations (Cardoso, 2002).

Germany, according to the Civil Code, has a highly developed legal system, where claims for legal protection of contractual and non-contractual legal relations can be satisfied through effective courts, complemented by a prosperous and well-maintained arbitration scene. However, there is a problem that includes the question of how to maintain a set of precedents in this area of legal relations (Federal Ministry of justice and Consumer Protection, n. d.).

Portugal is well aware of the importance of contractual and noncontractual relations. The Portuguese Civil Code has shaped its rules under the influence of EU law. The legal system and practice of Portugal in terms of contractual and non-contractual relations are constantly adapting to the conditions of the modern world (Government of Goa, 2018).

Particular attention is paid to contractual and non-contractual obligations in the Turkish Civil Code (International Labour Organization, 2001) and the Turkish Penal Code (European Commission for democracy through law, 2015). Turkey is a representative of the civil law system, and has a very liberal view, formed around the freedom of legal relations in this context. Turkish contractual relations contain reliable decisions on the conclusion of contracts, their invalidity or the consequences of the failure to fulfil or improper fulfilment of contractual obligations, as well as to compensate for losses that may be incurred by the parties. 
Swiss contractual and non-contractual relations are fully governed by the Swiss Civil Code, which has a long tradition and usually gives the parties more freedom to formalize their contractual relationship. Its basic legal principles have not changed for years, and no major changes are planned in the near future. This contributes to the legal certainty and predictability of the parties. Swiss civil and commercial courts tend to specialize and try to resolve disputes in a competent, pragmatic and efficient way. Besides, international commercial arbitration is very common and effective in Switzerland. Due to the independence and stability of the Swiss legal system, as well as its high level of freedom of contract, international parties often choose Swiss law as the applicable law of their contracts, and they provide for jurisdiction in Switzerland (Fedlex, 2021).

The Spanish Civil Code (Gobierno de España, n. d.), the French Civil Code (Legifrance, 2016) and the Federal Civil Code of Mexico (Portes Gil, 1928) set out the main provisions on the legal protection of participants in contractual and non-contractual relations, indicating the key principles on which legal protection is based in these countries.

The Civil Code of Ukraine (Verkhovna Rada of Ukraine, 2003) fully regulates the issues of contractual and non-contractual legal relations starting from their conditions and ending with legal protection in case of disputes. However, there is still a problem of the effectiveness of these rules and assessment of the practical protection of the parties.

Besides, the General Data Protection Regulation, which sets out contractual provisions and, in some cases, non-contractual ones that provide appropriate data protection guarantees, can be used as a basis for data transfer from the EU to third countries (European Commission, 2021).

Despite an extended legislative framework that seems to be exhaustive in regulating the protection of the rights and interests of participants in contractual and non-contractual legal relations, it can be observed that the effectiveness of legal protection cannot be called high in many countries. This is natural, on the one hand, because the requirements and needs of the parties are constantly changing and need other methods and approaches to their legal protection, and on the other - determines the readiness of states to seek new legal mechanisms to protect parties to contractual and non-contractual relations.

\section{Methods and Materials}

For a comprehensive analysis of the study of legal mechanisms to protect the rights of participants in contractual and non-contractual relations, we analysed the activities of some foreign countries, namely: Australia, Brazil, 
Serhï S. Sviatoshniuk, Liliia O. Bakalo, Oleg V. Bilostotskyi, Serhii F. Gut, Oleg I. Chaikovskyi y Oleksandr M. Zaiets

Spain, Mexico, Germany, Portugal, Turkey, France and Switzerland. These countries provide legal protection of the rights of participants in contractual and non-contractual legal relations in completely different ways, which allows a more specific approach to the study of this issue.

The study is based on an in-depth analysis of the legal framework of selected countries (Australia, Brazil, Spain, Mexico, Germany, Portugal, Turkey, France and Switzerland), which reflects the balance between different rules of legal protection and different intensity of protection.

Despite some similarities in the application of legal mechanisms to protect the rights and interests of participants in contractual and noncontractual legal relations and/or obligations, the level of their effectiveness and scope differ. Besides, the level of regulation and assessment of legal mechanisms to protect the rights and interests of participants in contractual and non-contractual legal relations in each country also differ.

This analysis was formed on the basis of official Internet resources of the studied countries and the current legal framework, so it fully complies with the mechanisms of legal protection of the rights and interests of participants in contractual and non-contractual relations in general.

The study involved methods of sociological analysis, which contributed to the generalization of international practice of legal mechanisms to protect the rights of participants in contractual and non-contractual relations, as well as analysis of empirical information, which further allowed comparing legal mechanisms to protect the rights of participants of the countries.

System-structural and comparative methods allowed exploring the legal background for the protection of the rights of participants in contractual and non-contractual relations and to compare them with each other.

Logical-semantic and formal-logical methods were used in the study of the level of legal protection of the rights and interests of participants in contractual and non-contractual legal relations, as well as determining the level of their effectiveness. Definitions are formulated within the research topic on their basis. The dialectical method was used in considering the studied problems and determining the main directions of development of legal mechanisms to protect the rights and interests of participants in contractual and non-contractual relations.

The theoretical background for the study was the works of domestic and foreign scientists, the regulatory framework of foreign countries, analytical information on legal mechanisms to protect the rights of participants in contractual and non-contractual relations in particular. 


\section{Results}

Today, the protection of the rights of participants in contractual and non-contractual legal relations directly depends on their legal protection mechanisms. For a comprehensive analysis of this issue, we propose to consider international experience in the field of legal mechanisms for the protection of contractual and non-contractual relations. Therefore, we propose to consider Table 1 and analyse the example of Spain, Germany, Turkey and France sanctions, which are conditions for the legal protection of these legal relations.

\section{Table 1. Conditions of protection of the rights of participants of contractual and non-contractual legal relations}

\begin{tabular}{|l|l|l|l|l|l|}
\hline Sanction & Description & & & & \\
& & & & & \\
\hline Performance & Performance of the contract & The & & \\
\hline $\begin{array}{l}\text { Termination of } \\
\text { the contract }\end{array}$ & $\begin{array}{l}\text { The damaged party has the right to } \\
\text { terminate the contract if the breach of } \\
\text { contract is significant and violates essential } \\
\text { terms }\end{array}$ & + & + & + & + \\
\hline $\begin{array}{l}\text { Price reduction in } \\
\text { some contracts }\end{array}$ & $\begin{array}{l}\text { There is a judicial tendency to provide a } \\
\text { price reduction in case of breach of contract }\end{array}$ & + & - & + & - \\
\hline $\begin{array}{l}\text { Liability for } \\
\text { hidden defects }\end{array}$ & $\begin{array}{l}\text { Obliges sellers to provide a warranty for } \\
\text { hidden defects }\end{array}$ & + & + & + & + \\
\hline $\begin{array}{l}\text { Compensation for } \\
\text { damages }\end{array}$ & $\begin{array}{l}\text { Breach of contract entails an obligation } \\
\text { for the violating party to compensate the } \\
\text { damage caused to the other party due to } \\
\text { failure to fulfil obligations }\end{array}$ & + & + & + & + \\
\hline
\end{tabular}

Source: Authors.

According to Table 1, we can see that Spain and Turkey have the highest legal protection of contractual and non-contractual relations. However, it should be noted that each country has its own peculiarities regarding their regulation. However, Germany and France involve more than one item of sanctions in the legal protection, which fully compensates for the other sanctions, which we will consider below. 
Serhï S. Sviatoshniuk, Liliia O. Bakalo, Oleg V. Bilostotskyi, Serhii F. Gut, Oleg I. Chaikovskyi y Oleksandr M. Zaiets

It is worth noting that under Spanish contract law, the parties have several remedies in the event of a breach of contract, which are not necessarily related to a particular type of breach. As a general rule, each party can choose the remedy that it considers most appropriate to protect its rights and interests, as there is no legal provision in Spanish law regarding the primacy of remedies. In fact, the plaintiff may also bring joint actions on a subsidiary basis (for example, the claim may be based on a specific performance and, if this is not possible, on damages) (Vendrell and Cepero, 2021). However, non-contractual relationships are governed by the parties themselves and, for the most part, if the parties cannot agree among themselves, their dispute is still resolved with an emphasis on contractual obligations.

In Germany, the simplest remedy is a performance claim. In sales contracts and work agreements, the buyer or customer should usually give the seller or contractor the opportunity to remedy the defect. This does not prevent the buyer or customer from claiming damages for the defect, such as property damage. German law on damages requires that the damaged party be placed in the position in which it would be if it hasn't incurred any losses through full compensation, lack of enrichment due to damages, limitation of liability, and repair work (Sattler, 2021). At the same time, contractual relations between the parties may arise much more often, as German law emphasizes the good faith of both parties. Therefore, when resolving disputes, both contractual and non-contractual legal relations are taken into account equally.

Examining the legal protection of Turkey on this issue, we traced such a feature as the fact that the parties are free to decide on the amount of the fine, which is not always dependent on the amount of damage. If the parties set the penalty less than the damage, the creditor may claim damages in excess of the fine, given that the debtor is at fault (Namli, 2021). Thus, Turkish law directly shows that it provides legal protection for any legal relations that arise between the parties. Moreover, if there are clearly defined terms of performance in the contractual obligations, but the parties have decided to change them on a non-contractual basis, they are considered equally legally significant.

The analysis of French contractual law is quite interesting, which provides five remedies available to the damaged party:

- exception in case of non-performance of obligations: a party may either refuse to perform its own obligation if the failure to perform of the contracting party is serious enough, or suspend the performance of its obligation when it is obvious that the other party will not perform.

- enforcement: the creditor of the obligation may receive enforcement of the specified obligation or assume the fulfilment of the obligation upon official notification. 
- price reduction: the creditor may accept, upon official notification, partial performance of the contract and demand a proportional price reduction.

- termination for violation: termination for violation can be applied on three grounds: application of the termination provision, court decision or unilateral termination. Unilateral termination of relations is the main innovation of the 2016 reform, according to which obligated persons may terminate contracts by notifying their debtors, if they have not eliminated the breach of contract, despite the official notification.

- damages: the creditor can receive compensation for the damage. Compensation will be reimbursed provided that the non-compliance is final or that a formal notice has been issued.

Besides, under French law, contractual liability applies between the contracting parties for any damage resulting from non-performance of a contractual obligation. Therefore, if these conditions are not met, the liability is non-contractual. In addition, in accordance with the principle of non-accumulation of contractual and non-contractual obligations, where the conditions of contractual liability are met, the party to the contract can no longer claim non-contractual liability. However, the case law recognises that the parties to a case may claim damages for both a contractual claim based on non-performance of a contract, and a non-contractual claim based on the abrupt termination of established commercial relations, even if these requirements are based on the same facts (Fages and Saarinen, 2021).

In Brazil, in case of breach of commercial agreement, the non-violating party has the opportunity to use various remedies, including:

- demand fulfilment of the overdue obligation.

- application of penalties provided for in the contract, if any;

- termination of the contract due to non-fulfilment of obligations by other parties.

- demand compensation in order to compensate for losses caused by nonfulfilment of obligations by counterparties (Gonçalves et al., 2021).

Based on the above provisions, it is clear that Brazilian law generally protects only contractual obligations, and only in the case of exceptions, can accept non-contractual relations by mutual agreement of the parties.

In the event of a breach of contract, the Portuguese legal system provides the non-violating party with several remedies: it may bring a declaratory action and demand specific enforcement in order to compel the infringing party to actually fulfil the contractual obligation. If the declaratory proceedings are successful, the creditor may file enforcement proceedings against the debtor, if the latter does not voluntarily comply with the court decision. 
Serhii S. Sviatoshniuk, Liliia O. Bakalo, Oleg V. Bilostotskyi, Serhii F. Gut, Oleg I. Chaikovskyi y Oleksandr M. Zaiets

A non-violating party may also claim compensation from the infringing party (including loss of profits) incurred as a result of breach of contract. However, the losses are not punitive but compensatory in Portugal. The non-violating party may also terminate the commercial contract in case of violation. However, under Portuguese law, termination is lawful only if the non-performance of the contract is serious and final. In the event of a delayed performance, the non-violating party will be able to terminate the contract only if it is no longer interested in the performance of the contract or if it has issued the defaulting party a fair notice to remedy the breach. In the event of termination, the non-violating party may demand compensation for the damage. However, as mentioned, the method of calculating compensation is controversial in Portugal (Aguilar De Carvalho, 2021). Thus, it should be added that contractual relations are more regulated in Portugal, while noncontractual obligations are rarely used by the parties.

Examining the legal protection of legal relations in Switzerland, it was noted that in the event of a breach of contract, the non-violating party usually has the option of either seeking specific enforcement or suing for damages. Depending on the type of contract and breach, a party may also have the right to terminate the contract, enforce warranty rights (such as repair or subsequent delivery), or go to court with reservations or other remedies (Rohn, 2021). That is, although non-contractual relations can still be applied, contractual obligations have much better legal protection.

Mexico is of particular interest to the study, where, as in most Latin American countries, Mexico's Federal Civil Code is based on the Napoleonic Civil Code, which means that Mexico adheres to the civil law system as opposed to the general (judicial) system. Therefore, the rules for concluding and interpreting treaties, breach of contract, and remedies are largely codified, as in other civil law countries. However, with regard to commercial litigation, Mexico is introducing a predominantly oral system, which is likely to become faster and more efficient. Thus, non-contractual obligations are the most common in Mexico, which helps to carry out proceedings in certain cases much faster (Obscura and Juarez, 2021).

The regulation of contractual and non-contractual relations in Australia It is quite interesting, where there is such a thing as a common law estoppel - a legal doctrine that can come into force in circumstances where the parties have departed from the strict terms of this agreement but did not enter into a new agreement to give effect to their new agreement. In essence, the common law of estoppel prevents a party in this situation from asserting its legal rights under the original agreement against the other party when it would be unfair, as this would lead the other party to assume that their basic agreement had changed. Common law applies only to assumptions about the current state of affairs, not to ideas about what will happen in the future (Lacey and Lewis, 2018). Thus, Australia has established the 
protection of non-contractual obligations to avoid possible bad faith of one of the parties.

Having analysed the foreign experience of contractual and noncontractual legal relations, it should be noted that in Ukraine contractual and non-contractual obligations are fully regulated by current legislation. However, its effectiveness should be considered quite controversial. This is due to the fact that, although the regulations provide for the protection of contractual relations and there is an exhaustive list of non-contractual relations, which include obligations arising from the public promise of remuneration; committing actions in the property interests of another person without his/her order; saving the health and life of an individual, property of an individual or legal entity; creating a threat to life, health, property of an individual or property of a legal entity; reparation; in practice the parties are not always convinced of their legal protection.

One of the reasons is that non-contractual obligations are very difficult to prove, which is not the case for the contractual obligations, where the terms of the legal relations are clearly defined. Besides, the ground for noncontractual obligations is not a contract, but legally significant actions that also need proof, as such actions can be both legal and illegal.

Thus, having carried out a comprehensive analysis of contractual and non-contractual obligations, it can be argued that all the conditions and further consequences that require legal protection are concentrated in their life cycle, which can be illustrated as shown on Figure 1.

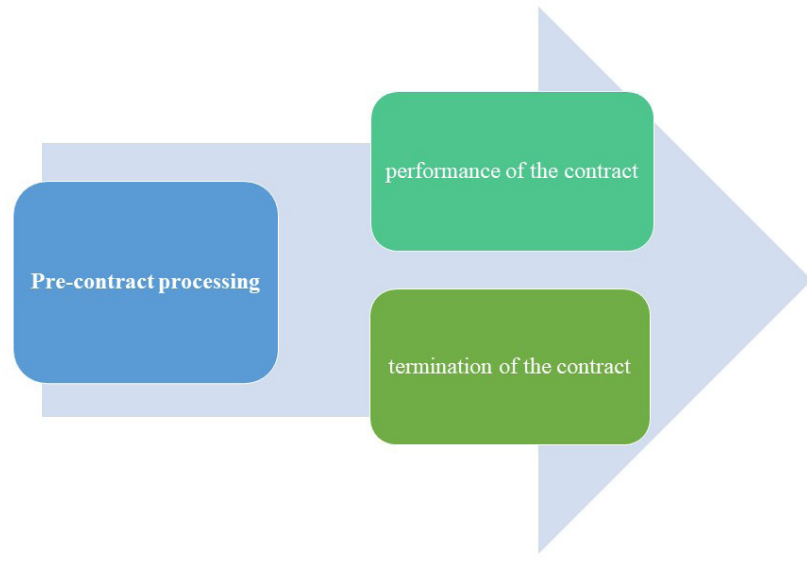

Figure 1: Life cycle of legal relations. Source: Prinsley and Yaros (2019) 
Serhii S. Sviatoshniuk, Liliia O. Bakalo, Oleg V. Bilostotskyi, Serhii F. Gut, Oleg I. Chaikovskyi y Oleksandr M. Zaiets

Legal Mechanisms for Protection of the Rights of Participants in Contractual and Non-Contractual Legal Relations

So, having studied the foreign experience of legal protection of contractual and non-contractual legal relations, it can be argued that their regulation and protection is not ambiguous. Therefore, we propose to consider Table 2 and determine which criteria provide legal protection in contractual and non-contractual relations, where "+" means "provide", and “_"-“do not provide”.

\section{Table 2. Assessment of legal protection of contractual and non-contractual legal relations by criteria}

\begin{tabular}{|l|c|c|}
\hline \multicolumn{1}{|c|}{ Criteria } & $\begin{array}{c}\text { Contractual } \\
\text { relations }\end{array}$ & $\begin{array}{c}\text { Non-contractual } \\
\text { relations }\end{array}$ \\
\hline $\begin{array}{l}\text { Effective performance of the contract / } \\
\text { agreement }\end{array}$ & + & - \\
\hline $\begin{array}{l}\text { Legislative requirements to support the } \\
\text { performance of contracts }\end{array}$ & + & - \\
\hline Alternative dispute resolution processes & + & + \\
\hline
\end{tabular}

Source: Organization of Economic Cooperation and Development (n.d)

On the basis of the countries that we studied, we propose to consider whether the protection of contractual and non-contractual relations is equal, where "+" means "full", and "_"__ "not full” (Table 3).

\section{Table 3. Level of legal protection of contractual and non-contractual legal relations}

\begin{tabular}{|c|l|c|c|}
\hline Item no. & \multicolumn{1}{|c|}{ Countries } & Contractual relations & Non-contractual relations \\
\hline 1 & Australia & + & + \\
\hline 2 & Brazil & + & - \\
\hline 3 & Spain & + & - \\
\hline 4 & Mexico & - & + \\
\hline 5 & Germany & + & + \\
\hline 6 & Portugal & + & - \\
\hline 7 & Turkey & + & + \\
\hline 8 & Ukraine & + & + \\
\hline 9 & France & + & + \\
\hline 10 & Switzerland & + & - \\
\hline Total & & 9 & 6 \\
\hline
\end{tabular}


So, having made a comparative analysis of contractual and noncontractual legal relations in Ukraine and foreign countries, we can see that although contractual obligations still occupy a higher position than non-contractual ones, the difference is quite small. Besides, it should be noted that most countries have a position of equal legal protection for both contractual and non-contractual obligations.

Based on the above, it should be emphasized that it is necessary to improve the regulation of non-contractual relations in modern conditions, as well as to pay attention not only to the legal protection of contractual and non-contractual obligations provided by the country on this issue, but also its effectiveness. Despite the availability of legal protection of both contractual and non-contractual legal relations in Ukraine, their effectiveness is quite low and needs legislative revision. The same applies to foreign countries, there are countries that focus on non-contractual relations, while the protection of contractual relations is imperfect, and vice versa. Therefore, there is an urgent need to review the legal framework for the effectiveness of protection of contractual and non-contractual obligations in accordance with modern conditions and needs of the parties to the existing legal relations.

\section{Discussion}

Having conducted research in the field of legal mechanisms for the protection of the rights of participants in contractual and noncontractual legal relations, it should be noted that it is difficult to call them unambiguous. Countries such as Australia, Germany, Turkey, Ukraine and France prefer to exercise legal protection to the same extent, although there are countries that adhere to the regulation of legal protection of mostly contractual obligations only - Brazil, Spain, Portugal, Switzerland, while some countries focus on non-contractual relations, such as Mexico.

Upon analysing the views of foreign scholars, we can agree with the statement that the legal protection of the rights of participants in contractual and non-contractual legal relations constantly requires legislative changes, as the effectiveness of legal protection of these obligations in the world is constantly changing.

Hryniak et al. (2018) conducted a study of the legal protection of contractual relations, which clarified the main reasons for the occurrence of contractual obligations and their relationship with non-contractual obligations.

The study of Wolff (2020), who examined the relationship between contract law and non-contract law in the field of property rights, is 
Serhii S. Sviatoshniuk, Liliia O. Bakalo, Oleg V. Bilostotskyi, Serhii F. Gut, Oleg I. Chaikovskyi y Oleksandr M. Zaiets

quite interesting. In his work, he provided comprehensive comparative characteristics of contractual legal relations that arise in this area with noncontractual ones.

Researchers Taylor and Taylor (2017) have noted that contractual and non-contractual relations are generally considered part of contract law. He explains this by the fact that regardless of the type of legal relations, there is a certain obligation of one party to another, and it depends not only on the existence of separately defined terms of the contract, but on noncontractual legal relations between the parties as well.

The research of Svirin et al. (2021) is worth being mentioned, as it analysed the current problems of legal qualification in international private law of contractual and non-contractual relations.

In analysing contractual and non-contractual relations, Brownsword (2017) identifies three broad goals that govern the predictable, real, and ideal functions of modern contract law, namely, to facilitate exchange, protect the public interest and the parties themselves, and provide a private dispute resolution mechanism. In his study, he identified the main characteristics of contractual and non-contractual relations.

However, Ramaekers (2017) emphasises in her research that contractual and non-contractual legal relations are completely different areas that need a different legal protection, although they may address the same issue.

Petrova's (2019) research is quite interesting, where in distinguishing between contractual and non-contractual legal relations she notes:

...when distinguishing between contractual and non-contractual obligations, in order to determine the applicable legislation, the first question to be resolved is whether this obligation corresponds to the contractual one or is closely related to the contractual one. If there is a close relationship with the contract, the obligation is primarily classified as contractual. Accordingly, when an obligation cannot be classified as a contractual, the obligation should be treated as a non-contractual obligation (Petrova, 2019: 37).

In his research on contractual and non-contractual legal relations, Teo (2021) focused not only on their characteristics and analysis, but also on the legal protection of the rights of participants and their legality. At the same time, he took into account the claims relating to both contractual and noncontractual legal relations, which led him to conclude on the different legal protection of contractual and non-contractual legal relations, depending on the country.

Besides, taking into account the current features, which include the COVID-19 pandemic, we reviewed the results of studies conducted by Zagonek and Boulatov (2020) who examined the legal impact on contractual obligations in a pandemic. They partially carried out a comparative analysis 
with non-contractual legal relations, which allowed tracing the main effects of the pandemic on these legal relations.

Györfi-Tóth (2020)_also conducted research on this issue, who also studied the impact of coronavirus as a potential force majeure event on contractual and non-contractual relations, while identifying the main characteristics of legal protection of participants in such relations.

\section{Conclusions}

The study of contractual and non-contractual legal relations as a legal mechanism to protect the rights of their participants is undeniably important for each country and society as a whole. The topic of this article attracts the attention of researchers and scholars not only to theoretically consider this topic, but also to provide their recommendations for improving the legal protection of the rights of participants in legal relations.

Based on the study of foreign experience, the scope of regulation of legal mechanisms of protection through legal acts is considered and their efficiency is assessed in such countries as Australia, Brazil, Spain, Mexico, Germany, Portugal, Turkey, France and Switzerland.

Having conducted a comprehensive analysis of the mechanisms for legal protection of the rights of participants in contractual and non-contractual legal relations on the example of foreign countries, it should be noted that there is a need to expand legal mechanisms for legal protection of the rights of participants in legal relations. In particular, amendments should be made to the regulations of most of the countries we studied, because they either do not regulate this area of legal relations in full, or there are problems with the effectiveness of already established rules that should provide legal protection for both contractual and non-contractual relations. As a result, this is directly reflected in the statistics compiled to analyse the activities of countries, which allows us to realistically assess the position of a country in the context of protecting the rights of the parties to the legal relations.

The obtained results can be used in research, law-making, law enforcement and educational process. For example, research provides a background for further theoretical studies of legal mechanisms to protect the rights of participants in contractual and non-contractual relations, which are aimed at improving the system of protection of citizens' rights.

It is necessary to take into account the obtained results in law-making, because the study resulted in proposals to improve the legal protection of the rights of participants in contractual and non-contractual relations. Application in law enforcement activities will allow improving the legal protection of the parties to legal relations and increasing the effectiveness 
Serhii S. Sviatoshniuk, Liliia O. Bakalo, Oleg V. Bilostotskyi, Serhii F. Gut, Oleg I. Chaikovskyi y Oleksandr M. Zaiets

of the introduction of mechanisms for legal protection of participants in contractual and non-contractual legal relations. The use of the results of this study in the educational process is equally important, as they can be introduced in educational materials on the subjects that involve studying the legal protection of contractual rights in law and other educational institutions.

\section{Bibliographic References}

AGUILAR DE CARVALHO, Fernando. 2021. The complex commercial litigation law review: Portugal. Available online. In: https://thelawreviews. co.uk/title/the-complex-commercial-litigation-law-review/portugal. Consultation date: 25/04/2021.

BROWNSWORD, Roger. 2017. General considerations. In: Michael Furmston (Ed.), The Law of Contract, 6th edition (pp. 23-25). LexisNexis. London, UK.

CARDOSO, Fernando Henrique. 2002. Brazilian Civil Code. Law No. 10.406. Available online. In: https://wipolex.wipo.int/en/text/226198. Consultation date: 25/02/2021.

EUROPEANCOMMISSION FOR DEMOCRACYTHROUGH LAW. 2015. Penal Code of Turkey 2004. Available online. In: https://www.legislationline. org/download/id/6453/file/Turkey_CC_2004_am2016_en.pdf. Consultation date: 25/02/2021.

EUROPEAN COMMISSION. 2021. Standard contractual clauses. Available online. In: https://ec.europa.eu/info/law/law-topic/data-protection/ international-dimension-data-protection/standard-contractual-clausesscc_en. Consultation date: 25/10/2021.

FAGES, Fabrice; SAARINEN, Myria. 2021. The complex commercial litigation law review: France. Available online. In: https://thelawreviews. co.uk/title/the-complex-commercial-litigation-law-review/france. Consultation date: 25/04/2021.

FEDERAL MINISTRY OF JUSTICE AND CONSUMER PROTECTION. n. d. Bürgerliches Gesetzbuch [Civil law book.]. Available online. In: https:// www.gesetze-im-internet.de/bgb/BJNRoo1950896.html. Consultation date: $25 / 02 / 2021$.

FEDLEX. 2021. Swiss Civil Code 1907. Available online. In: https://www.fedlex. admin.ch/eli/cc/24/233_245_233/en. Consultation date: 25/02/2021. 
GOBIERNO DE ESPAÑA. n. d. Código civil [Civil code]. Available online. In: https://www.boe.es/eli/es/rd/1889/o7/24/(1)/con. Consultation date: 25/02/2021.

GONÇALVES, Diógenes; SILVA, Elder Avelino; ARDITO, Gianvito; ZANETTI, Pedro Ivo Gil. 2021. The complex commercial litigation law review: Brazil. Available online. In: https://thelawreviews.co.uk/title/thecomplex-commercial-litigation-law-review/brazil. Consultation date: 25/04/2021.

GOVERNMENT OF GOA. 2018. Portuguese Civil Code 1867.Official translation with notes. First edition. Available online. In: https://www.indiacode. nic.in/bitstream/123456789/8312/1/ocrportuguesecivilcode.pdf. Consultation date: 25/02/2021.

GYÖRFI-TÓTH, Peter. 2020. Impact of Coronavirus as a potential force majeure event on private law contractual relationships in Hungary. Available online. In: https://www.dlapiper.com/ru/russia/insights/ publications/2020/o4/impact-of-coronavirus-on-private-lawcontractual-relationships-in-hungary/. Consultation date: 25/03/2021.

HRYNIAK, Andrii B; KOT, Oleksii O; PLENIUK, Mariana D. 2018. “Contractual regulation of relations of joint ownership of individuals in Ukraine (on the example of agreements on the transfer of property into ownership)" In: Utopía y Praxis Latinoamericana. Vol. 23, No. 82, pp. 209-221.

INTERNATIONAL LABOUR ORGANIZATION. 2001. Civil Code Turkey. Act No. 4721. Available online. In: https://www.ilo.org/dyn/natlex/natlex4. detail?p_isn=61757\&p_lang=en. Consultation date: 25/02/2021 .

KANASHEVSKII, Vladimir Aleksandrovich. 2019. Private International Law: Textbook. Mezhdunarodnye otnosheniya. Moscow, Russia.

LACEY, Andrew; LEWIS, Guy. 2018. The non-contractual ties that bind. Available online. In: https://www.lexology.com/library/detail. aspx?g=4c8f2a95-a987-43bc-8280-8bafad800059. Consultation date: 25/02/2021.

LEGIFRANCE. 2016. Code civil français [French civil code]. Available online. In: https://www.legifrance.gouv.fr/codes/texte_lc/LEGITEXTo00006070 721? etatTexte=VIGUEUR\&etatTexte=VIGUEUR_DIFF. Consultation date: $25 / 02 / 2021$.

NAMLI, Mert. 2021. The complex commercial litigation law review: Turkey. Available online. In: https://thelawreviews.co.uk/title/thecomplex-commercial-litigation-law-review/turkey. Consultation date: 25/04/2021. 
Serhii S. Sviatoshniuk, Liliia O. Bakalo, Oleg V. Bilostotskyi, Serhii F. Gut, Oleg I. Chaikovskyi y Oleksandr M. Zaiets

OBSCURA, Javier Curiel; JUAREZ, Ernesto Palacios. 2021. The complex commercial litigation law review: Mexico. Available online. In: https:// thelawreviews.co.uk/title/the-complex-commercial-litigation-lawreview/mexico. Consultation date: 25/04/2021.

ORGANIZATION OF ECONOMIC COOPERATION AND DEVELOPMENT. n. d. Contract enforcement and dispute resolution. Available online. In: https://www.oecd.org/investment/toolkit/policyareas/ investmentpolicy/contractenforcementanddisputeresolution.htm. Consultation date: 25/03/2021.

PETROVA, Galina Vladislavovna. 2019. Private International Law: Textbook for Academic Bachelor's Degree in 2 Volumes. Vol. 1. Urait. Moscow, Russia.

PORTES GIL, Emilio. 1928. Federal Civil Code. Available online. In: https:// www.global-regulation.com/translation/mexico/560097/federal-civilcode.html. Consultation date: 25/02/2021.

PRINSLEY, Mark A; YAROS, Oliver. 2019. Using performance of a contract as a legal basis for processing in the context of online services. Available online. In: https://www.mayerbrown.com/en/perspectives-events/ publications/2019/05/using-performance-of-a-contract-as-a-legalbasis-for-processing-in-the-context-of-online-services. Consultation date: $25 / 02 / 2021$.

RAMAEKERS, Eveline. 2017. "What is property law?" In: Oxford Journal of Legal Studies. Vol. 37, No. 3, pp. 588-591.

ROHN, Patrick. 2021. The complex commercial litigation law review: Switzerland. Available online. In: https://thelawreviews.co.uk/title/thecomplex-commercial-litigation-law-review/switzerland. Consultation date: 25/04/2021.

SATTLER, Maximilian. 2021. The complex commercial litigation law review: Germany. Available online. In: https://thelawreviews.co.uk/title/thecomplex-commercial-litigation-law-review/germany. Consultation date: 25/04/2021.

SVIRIN, Yury Alexandrovich; MOKHOV, Alexandr Anatolievich; FOMENKO, Elena Vladimirovna; ARTYUKHOV, Eduard Eduardovich; SHESTOV, Sergej Nikolaevich. 2021. "Problems of legal qualification in private international law" In: Geintec. Vol. 11, No. 4, pp. 812-825.

TAYLOR, Richard; TAYLOR, Damian. 2017. Contract Law: Directions, 6th edition. Oxford University Press, 392 p. Oxford, UK. 
TEO, Marcus. 2021. Foreign law illegality and non-contractual claims. Available online. In: https://conflictoflaws.net/2021/foreign-law-illegality-andnon-contractual-claims/. Consultation date: 25/03/2021.

VENDRELL, Carles; CEPERO, Miguel Ángel. 2021. The complex commercial litigation law review: Spain. Available online. In: https://thelawreviews. co.uk/title/the-complex-commercial-litigation-law-review/spain. Consultation date: 25/02/2021.

VERKHOVNA RADA OF UKRAINE. 2003. The Civil Code of Ukraine. The Law from 16.01.2003 № 435-IV. Available online. In: https://zakon.rada. gov.ua/laws/show/435-15\#Text. Consultation date: 25/02/2021.

WOLFF, Lutz-Christian. 2020. "The relationship between contract law and property law" In: Common Law World Review. Vol. 49, No. 1, pp. 31-55.

ZAGONEK, Julia; BOULATOV, Pavel. 2020. COVID-19: Legal impact on contractual obligations. Available online. In: https://www.whitecase. com/publications/alert/covid-19-legal-impact-contractual-obligations. Consultation date: 25/03/2021. 

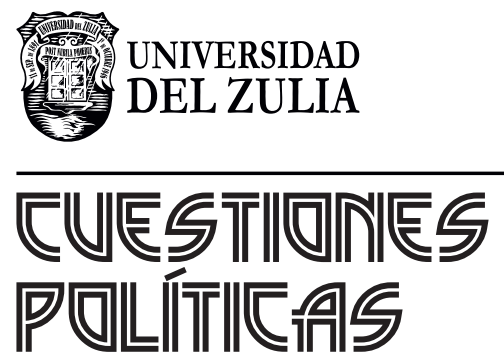

Vol. 39 N $^{\circ} 71$

Esta revista fue editada en formato digital y publicada en diciembre de 2021, por el Fondo Editorial Serbiluz, Universidad del Zulia. Maracaibo-Venezuela 